\title{
AFLP analysis reveals infraspecific phylogenetic relationships and population genetic structure of two species of Aconitum in Central Europe
}

\author{
Józef Mitka ${ }^{1 *}$, Piotr Boroń ${ }^{2}$ Ada Wróblewska ${ }^{3}$, Wojciech Bąba ${ }^{1}$ \\ ${ }^{1}$ Institute of Botany, Jagiellonian University, Kopernika 27, 31-501 Cracow, Poland \\ ${ }^{2}$ Institute of Forest Ecosystem Protection, University of Agriculture in Krakow, 29 Listopada 46, 31-425 Cracow, Poland \\ ${ }^{3}$ Institute of Biology, University of Bialystok, Ciołkowskiego 1j, 15-245 Białystok, Poland
}

\begin{abstract}
The genetic diversity of two Aconitum species endemic to the Carpathian Mountains and Sudetes was studied. A reticulate evolution between them was earlier postulated as an effect of secondary contact. The genetic diversity at the individual and taxonomic levels was examined across the entire geographical ranges of the taxa in 11 populations based on 247 AFLP markers found in 112 individuals in the Sudetes and Western Carpathians. The overall genetic differentiation was greater within the Sudetic A. plicatum $\left(F_{\mathrm{ST}}=0.139, P<0.001\right)$ than within the Carpathian $A$. firmum $\left(F_{\mathrm{ST}}=0.062, P<0.001\right)$, presumably due to the long-lasting geographic isolation between the Giant Mts and Praděd (Sudetes) populations of the species. Interestingly, relatively distant and presently isolated populations of A. plicatum and A. $f$. subsp. maninense share a part of their genomes. It could be an effect of their common evolutionary history, including past and present reticulations. The introgression among infraspecific taxa of Aconitum is common, probably as a result of seed dispersal within a distance of ca. $20 \mathrm{~km}$ (Mantel's $r=0.36, P=0.01$ ). Aconitum $f$. subsp. maninense had the highest genetic diversity indices: Nei's $h$ and rarefied $F A r$, and divergence index $D W(P \leq 0.05)$, pointing to its presumably ancient age and long-term isolation.
\end{abstract}

Keywords: Carpathians; introgression; Linnaean taxonomy; phylogenetics; population genetics; reticulate evolution; Sudetes

\section{Introduction}

In Europe, the monkshood genus, Aconitum L. (Ranunculaceae), subgenus Aconitum, is circumscribed within two sections: Aconitum L. (the tetraploids [1]) and Cammarum DC. (the diploids [2]). The diploids are mainly forest plants that occur in lower mountains and in the lowlands, the tetraploids are as a rule high-mountain taxa [3]. The Western Carpathians and Sudetes, two neighboring mountain systems dissected by the Moravian Gate (Moravská brána/Brama Morawska), have different geological histories and ages. They possess two endemic species of Aconitum sect. Aconitum: A. firmum Rchb. in the Carpathians, and A. plicatum Rchb. in the Sudetes (Tab. 1, p. 13 in [4]). In the Sudetes, two subspecies have been distinguished: subsp. plicatum and subsp. sudeticum Mitka [4]. The latter subspecies is an Eastern Sudetic endemic that occurs in the Wysoki Jesionik/Hruby Jeseník and Masyw Śnieżnika/Králický Snežnik. Aconitum firmum in the West Carpathians is divided into the three

* Corresponding author. Email: j.mitka@uj.edu.pl

Handling Editor: Krzysztof Spalik subspecies: subsp. firmum, subsp. moravicum Skalický and subsp. maninense (Skalický) Starmühl. [4,5]. Cytogenetic investigations with the Giemza C-band staining revealed that A. plicatum is an autopolyploid, and A. firmum is an allopolyploid species [3]. Aconitum $f$. subsp. maninense and A. p. subsp. sudeticum are of special interest since they share an unusual morphological character in the sect. Aconitum, which is glandular indumentum (Fig. 22i-k, p. 189 in [3], [5]). Generally, Aconitum species hybridize both within $[1,2,6,7]$ and between sections [8-10].

Recent studies in the Western Carpathians and Eastern Sudetes showed a reticulate evolution of Aconitum, probably dating back to the last glaciation [3]. During the Quaternary some oligothermic, high-mountain taxa, including monkshood, might have descended to lower altitudes and then came into secondary contact [11]. This could facilitate the genetic introgression and the origin of morphological similarities. In Aconitum the cryptic introgression, i.e. the admixture of alien genes not accompanied by the morphological changes, was to be found [12]. The hypothesis on gene flow between the Sudetic and Carpathian Aconitum is assessed by testing relationships between the genetic and taxonomic structure of the populations. In the present study, 
Tab. 1 Population numbering, including their taxonomic differentiation, location, elevation (above sea level), sample size $(N)$, percentage of polymorphic loci $(P P B), h$ - Nei's index of gene diversity, $I$ - rarefied Shannon's index of diversity, $S$ - Simpson's diversity index, $D W$ - rarity index corresponding to "frequency-down-weighted marker values" per population, $F A$ - average number of ISSR fragments per individual, $F A r$ - rarefied $F A$ values.

\begin{tabular}{|c|c|c|c|c|c|c|c|c|c|c|c|c|c|}
\hline No. & Code & Taxon & $\begin{array}{l}\text { Region/ } \\
\text { Locality }\end{array}$ & $\begin{array}{c}\text { Coordinates } \\
\text { N, E }\end{array}$ & $\begin{array}{l}\text { Elevation } \\
\text { (m a.s.l.) }\end{array}$ & $N$ & $P P B$ & $\boldsymbol{h}$ & $I$ & $1-S$ & $D W$ & $F A$ & $F A r$ \\
\hline $1 \mathrm{~A}$ & FB & firmum & $\begin{array}{l}\text { Beskid } \\
\text { Żywiecki/Babia } \\
\text { Góra Massif }\end{array}$ & $49.34,19.31$ & 1225 & 10 & 47.8 & 0.142 & 4.692 & 0.011 & 1.702 & 56.2 & 83.0 \\
\hline $1 \mathrm{~B}$ & $\mathrm{MB}$ & moravicum & & $49.34,19.31$ & 1225 & 10 & 50.2 & 0.139 & 4.728 & 0.011 & 1.746 & 59.9 & 83.0 \\
\hline $2 \mathrm{~A}$ & FG & firmum & $\begin{array}{l}\text { Tatra Mts./ } \\
\text { Gęsia Szyja }\end{array}$ & $49.15,20.04$ & 1450 & 10 & 46.2 & 0.144 & 4.678 & 0.010 & 1.845 & 63.7 & 84.0 \\
\hline $2 \mathrm{~B}$ & MG & moravicum & & $49.15,20.04$ & 1450 & 5 & 42.5 & 0.151 & 4.632 & 0.009 & 1.642 & 59.6 & 87.0 \\
\hline $3 \mathrm{~A}$ & FPo & firmum & $\begin{array}{l}\text { Beskid } \\
\text { Żywiecki/Polica }\end{array}$ & $49.37,19.36$ & 1220 & 5 & 35.6 & 0.119 & 4.459 & 0.011 & 1.342 & 59.8 & 77.0 \\
\hline $3 B$ & MPo & moravicum & & $49.37,19.36$ & 1220 & 3 & 34.8 & 0.142 & 4.454 & 0.008 & 1.854 & 61.0 & 86.0 \\
\hline 4 & $\mathrm{MBa}$ & moravicum & $\begin{array}{l}\text { Beskid Śląski/ } \\
\text { Barania Góra }\end{array}$ & $49.36,19.00$ & 1050 & 10 & 52.2 & 0.148 & 4.766 & 0.010 & 1.937 & 63.1 & 86.0 \\
\hline 5 & $\mathrm{MCh}$ & moravicum & $\begin{array}{l}\text { Mala Fatra/ } \\
\text { Chleb }\end{array}$ & $49.10,19.02$ & 1220 & 5 & 41.7 & 0.152 & 4.616 & 0.010 & 1.902 & 57.4 & 87.0 \\
\hline 6 & $\mathrm{MC}$ & moravicum & $\begin{array}{l}\text { Moravskoslezske } \\
\text { Beskids/ } \\
\text { Čeladna }\end{array}$ & $49.29,18.20$ & 590 & 5 & 39.3 & 0.143 & 4.557 & 0.010 & 1.683 & 58.8 & 83.0 \\
\hline 7 & MP & moravicum & $\begin{array}{l}\text { Beskid } \\
\text { Żywiecki/Pilsko }\end{array}$ & $49.32,19.19$ & 1280 & 10 & 47.0 & 0.140 & 4.669 & 0.011 & 1.536 & 60.3 & 82.0 \\
\hline 8 & Ma & maninense & $\begin{array}{l}\text { Stražovske } \\
\text { vrchy/Manín }\end{array}$ & $49.08,18.30$ & 430 & 9 & 49.8 & 0.166 & 4.750 & 0.010 & 1.943 & 59.3 & 88.0 \\
\hline 9 & $\mathrm{Mu}$ & maninense & $\begin{array}{l}\text { Tatra Mts./ } \\
\text { Murzasichle }\end{array}$ & $49.18,20.02$ & 940 & 10 & 51.4 & 0.165 & 4.779 & 0.010 & 2.549 & 54.1 & 89.0 \\
\hline \multirow[t]{3}{*}{ Total } & & firmum & $\begin{array}{l}\text { Western } \\
\text { Carpathians }\end{array}$ & - & $1220-1225$ & 25 & 43.2 & $0.135^{\mathrm{a}}$ & 4.610 & 0.011 & $1.630^{\mathrm{a}}$ & 59.9 & $81.3^{\mathrm{a}}$ \\
\hline & & moravicum & $\begin{array}{l}\text { Western } \\
\text { Carpathians }\end{array}$ & - & $590-1450$ & 48 & 43.9 & $0.145^{\mathrm{a}}$ & 4.632 & 0.010 & $1.757^{\mathrm{a}}$ & 60.0 & $84.9^{\mathrm{a}}$ \\
\hline & & maninense & $\begin{array}{l}\text { Western } \\
\text { Carpathians }\end{array}$ & - & $430-940$ & 19 & 50.6 & $0.166^{\mathrm{b}}$ & 4.765 & 0.010 & $2.246^{\mathrm{b}}$ & 56.7 & $88.5^{\mathrm{b}}$ \\
\hline Total & & A. firmum agg. & W Carpathians & - & $430-1450$ & 92 & $47.8^{\mathrm{a}}$ & 0.146 & 4.648 & 0.010 & $1.807^{a}$ & 59.4 & $84.6^{\mathrm{a}}$ \\
\hline 10 & SS & sudeticum & $\begin{array}{l}\text { Hruby Jesenik/ } \\
\text { Keprnik }\end{array}$ & $50.09,17.06$ & 1330 & 10 & 62.3 & 0.194 & 4.968 & 0.008 & 5.107 & 61.6 & 100.0 \\
\hline 11 & SP & plicatum & $\begin{array}{l}\text { Giant Mts/ } \\
\text { Wodospad } \\
\text { Łomniczki }\end{array}$ & $50.44,15.43$ & 1250 & 10 & 50.6 & 0.149 & 4.738 & 0.010 & 2.583 & 61.5 & 85.0 \\
\hline Total & & A. plicatum agg. & Sudetes & - & $1250-1330$ & 20 & $56.4^{\mathrm{b}}$ & 0.172 & 4.853 & 0.009 & $3.845^{\mathrm{b}}$ & 61.6 & $92.5^{\mathrm{b}}$ \\
\hline Grand total & & sect. Aconitum & C Europe & - & - & 112 & 46.5 & 0.150 & 4.678 & 0.010 & 2.098 & 59.7 & 85.7 \\
\hline
\end{tabular}

The different superscripts denote statistical significance of the differences $(P \leq 0.05)$. Taxon - names of subspecies, excluding $A$. firmum agg. and A. plicatum agg., i.e. specific rank.

we aimed to determine the genetic structure of $A$. plicatum in the Sudetes and A. firmum in the Western Carpathians. In particular, we addressed the following questions: $(i)$ do present-day genetic patterns within and between the two Aconitum species in the Carpathians and Sudetes indicate past exchange of genetic material; (ii) are there differences in AFLP profiles between disjunct populations in the Western Carpathians and those in the Sudetes; (iii) is any subspecies within $A$. firmum genetically different from the remaining infraspecific taxa?

\section{Material and methods}

\section{Study area}

The investigations were carried out in two mountain ranges: the Carpathians and Sudetes. They differ in their geological substratum and time of origin. The Sudetes represent the northeastern-most outcropping segment of the Central European Variscan (Hercynian) Belt affected by Devonian to late Carboniferous sedimentation [13,14], and the Western Carpathians belong to the geologically younger 
European Alpine System [15] formed at the Oligocene/ Miocene boundary [16,17].

\section{Sampling methods}

Samples were randomly collected from 11 populations of Aconitum sect. Aconitum across its geographical range in the Sudetes and Western Carpathians in August and September of 2011-2012 (Fig. 1). Each specimen in samples was determined and then each taxon recognized was analyzed separately. Samples 1-3 were taxonomically mixed and consisted of $A$. firmum Rchb. subsp. firmum and $A$. $f$. subsp. moravicum Skalický, while the remaining samples were uniform, with the following taxa represented: $A$. $f$. subsp. maninense (Skalický) Starmühl., A. plicatum Rchb. subsp. plicatum and A. p. subsp. sudeticum Mitka (Tab. 1). Taxonomy and nomenclature of Aconitum in the Carpathians and Sudetes follow Mitka [4].

\section{DNA extraction and AFLP analysis}

Genomic DNA was extracted from dry leaf tissue with the Genomic Mini AX Plant kit (A \& A Biotechnology). The AFLP procedure followed Vos et al. [18], but modified according to the Applied Biosystems protocol (AFLP ${ }^{\mathrm{T}}$ Plant Mapping). First, 32 primer pair combinations were tested on four selected samples. The fluorescence-labeled selective amplification products were mixed with $500 \mathrm{Liz}$ labeled size standard (Applied Biosystems) and run on an ABI 3130. Then, from this analysis we chose the three primer combinations that gave polymorphic, clear, reproducible fragments of homogeneous intensity: EcoR1-AGG/MseICAC; EcoR1-AGG/MseI-CAG; EcoR1-ACG/MseI-CAG. Variable fragments in the 70-500 bp size range were scored as present (1) or absent (0) using GeneMapper 4.0 (Applied Biosystems). To test the repeatability of AFLP results, $10 \%$ of all individuals were completely replicated starting from restriction-ligation AFLP reaction. Error rate was checked with the method recommended by Bonin et al. [19].

\section{Data analysis}

Basic diversity indices for each taxon and population were calculated. The percentage of polymorphic bands $(P P B)$ and Nei's gene diversity index $(h)$ [20] were computed based on the allele frequency matrix in accordance with the Bayesian method with a non-uniform prior distribution of allele frequencies [21] using AFLP-SURV software version 1.0 [22]. In addition, mean number of alleles (bands) per individual $(F A)$ in the population, rarefied total number of alleles in the population (FAr), and Shannon's index of diversity $(I)$ per population were computed with $\mathrm{R}$ software [23] and vegan package [24]. Because these indices are sensitive to sample size, the calculations should be standardized (rarefied) in order to estimate allelic richness at locus for a fixed sample size. Therefore, rarefaction was performed using the rarefy function of $\mathrm{R}$ package vegan, which gave the expected allele richness and their standard errors [24]. R function drarefy returns probabilities that alleles occur in a rarefied community. These values were used for calculation of Shannon's index $I$ with the vegan function diversity. We calculated the unbiased Simpson's index of concentration in a form 1-S, which represents the probability that two fragments from a population will belong to different individuals. In addition, we computed the rarity index $(D W)$ corresponding to "frequency-down-weighted marker values" per population [25]. This index is believed to attain high values in long-term

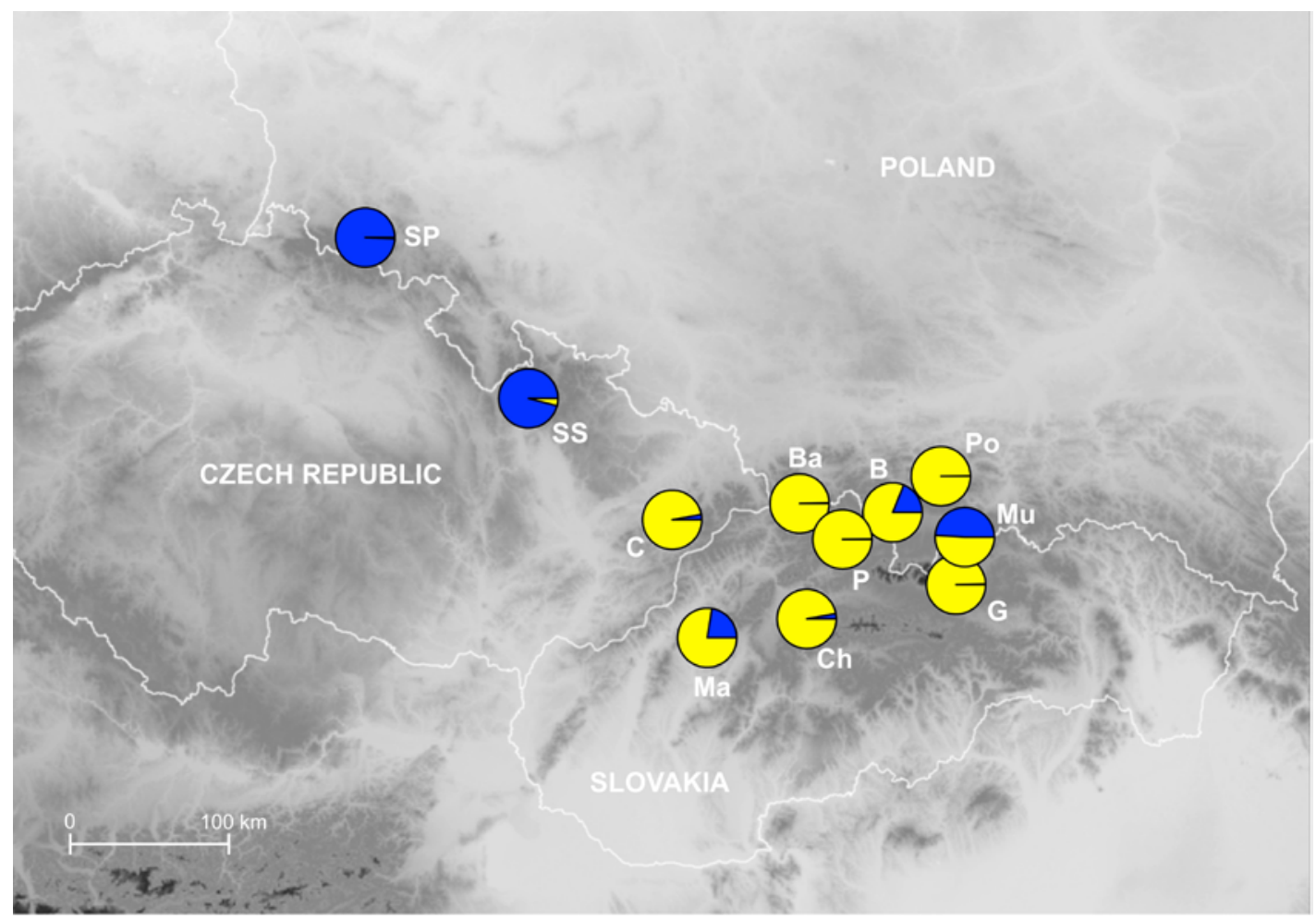

Fig. 1 The localities of sect. Aconitum populations in the Sudetes and W Carpathians and their genetic partitioning according to a Bayesian STRUCTURE analysis. C - Čeladna; Ch - Mt Chleb; B - Babia Góra Massif; Ba - Barania Góra; G - Gęsia Szyja; Po - Polica; Ma - Manin; Mu - Murzasichle; P - Pilsko; SS - Keprnik; SP - Wodospad Łomniczki (for description of localities see Tab. 1). 
isolated relict populations where rare markers should accumulate due to mutations, whereas newly established populations are expected to exhibit low values.

The relationships among individuals, populations and taxa were analyzed by a principal coordinate analysis (PCoA) ordination at the individual level based on Nei-Li genetic distance [26] and the population level based on Nei unbiased genetic distance [27], calculated with $\mathrm{ADE}-4$ package $[23,28]$. In addition NeighbourNet (NN) dendrogram at the individual level, based on Nei-Li genetic distance, was generated with the SplitsTree4 software [29]. In order to assign the individuals sampled to the $K$ genetic clusters, we used the spatially implicit approach offered by the software STRUCTURE 2.2.3 [30-32]. We implemented the admixture model, which accounts for allele frequency correlations across populations without prior population information [30,31]. We modeled cluster assignments for $K=2-15$ clusters (the number of sites studied plus one). The distribution of posterior probabilities, $\ln \operatorname{Pr}(\mathrm{K} \mid \mathrm{X})$, and their variance were examined for 10 independent runs for each value of $K$. In all simulations we found that a burn-in of $2 \times 10^{5}$ iterations and $1 \times 10^{6}$ Markov-chain Monte Carlo (MCMC) iterations yielded consistent results confirming a strong signal from the data. Outputs of all STRUCTURE runs were analyzed using the R-script Structure-sum [33]. Average similarity coefficients among runs were calculated for each $K$ to verify the consistency of replicated runs. From different methods for estimating the optimal number of genetic clusters using Bayesian assignment techniques [30,34], we chose the quantity $\Delta K$ [35], which is an ad hoc estimator of the second order rate of change of the $\ln \operatorname{Pr}(\mathrm{K} \mid \mathrm{X})$, and which should show a peak in the "true" value of the number of clusters. Evanno et al. [35] demonstrated that the peaks of modal value(s) of $\Delta K$ were good estimates of $K$ for a simulated dataset with known population sizes, types and numbers of loci. The number of clusters $(K)$ was chosen based on two criteria: $(i)$ the stability of the assignment, and (ii) the second-order rate of change of the log likelihood function with respect to $K(\Delta K)$.

The analysis of molecular variance (AMOVA) was employed to describe the genetic partitioning between the two species and among subspecies of A. firmum and A. plicatum, using ARLEQUIN 3.1 [36].

Mantel tests were calculated to quantify the correlations between geographical and Nei's genetic distances. The Mantel correlogram (the multivariate analogue of the spatial correlogram) based on normalized Mantel $r$-statistic was computed with 999 permutations using R Package and function "mantel.correlog" in the package vegan $[37,38]$. We used Pearson's product-moment correlations with option "n.class", which defines number of distance classes. Probabilities of Mantel's $r$-values were sequentially Bonferroni-adjusted.

The Pearson correlation coefficient was used to check the possible correlation between the indices of the genetic diversity and the number of individuals. The differences between certain genetic diversity parameters among taxa were checked with multiple comparison test $z$ after Kruskal-Wallis analysis $(\alpha=0.05)$, computed with STATISTICA 10 software (StatSoft, Inc.).

\section{Results}

In total, 247 polymorphic AFLP fragments were evaluated. Data quality tests indicated overall repeatability of AFLP bands above $98 \%$. At the taxonomic level, the percentage of polymorphic loci, Nei's, Shannon's and Simpson's indices of the genetic diversity were the highest in A. plicatum and the lowest in $A$. firmum. The average number of bands per individual, $F A r$, was significantly higher in A. plicatum (92.5) than in $A$. firmum (84.6, $P<0.05$; Tab. 1). Within A. firmum the highest, statistically significant difference in values of genetic diversity were in both the percentage of polymorphic markers $P P B$ and the frequency-downweighted marker value $D W$ of $A$. $f$. subsp. maninense. The $P P B$ index ranged from $34.8 \%$ (A. f. subsp. moravicum, Western Carpathians, denoted as MPo in Tab. 1) to $62.3 \%$ (A. p. subsp. sudeticum, Sudetes, SS). The mean number of rarefied bands per individual $F A r$ in the population varied from 77 (A. $f$. subsp. firmum, Western Carpathians, FPo) to 100 (A. p. subsp. sudeticum, Sudetes, SS), with a mean 85.7. The 1-S index of intrapopulation diversity was the highest, 0.011 in the population FB (A.f. subsp. firmum) and the lowest, 0.008 in the population SS (A. p. subsp. sudeticum), with a mean 0.010 The $D W$ index ranged from 1.342 (A.f. subsp. firmum, Western Carpathians, FPo) to 5.107 (A. p. subsp. sudeticum, Sudetes, SS), with a mean 2.098.

The following indices of genetic diversity were dependent on the population size: percentage of the polymorphic loci $P P B(r=0.84)$, Shannon's index $I(r=0.80)$, and mean number of bands per individual, $F A$, in the population $(r=0.83$, all $P \leq 0.05)$. The correlation between the population size and rarefied mean number of bands per individual in the population, $F A r$, was low and statistically insignificant $(r=0.22$, $P>0.05)$. In contrast, all genetic indices were significantly correlated with $F A r$ (Fig. 2). The indices of genetic diversity: the $P P B$ index, rarity index $D W$ and the rarefied number of bands per individual, $F A r$, were the highest in A. plicatum.

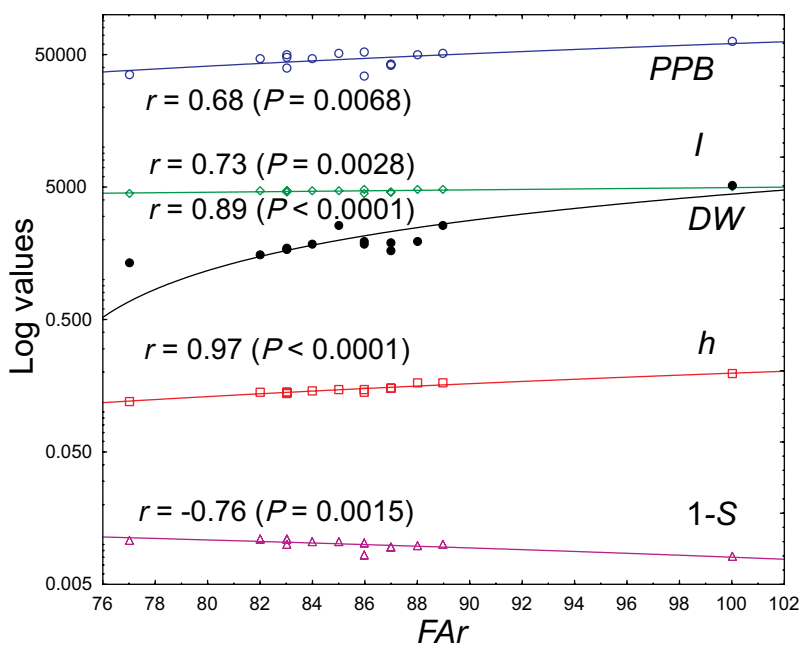

Fig. 2 Pearson's correlations between mean rarefied number of AFLP bands (alleles) per individual in the population (FAr) and the remaining population-genetic diversity indices: $P P B$ - percentage of polymorphic bands, $h$ - Nei's index of gene diversity, $I$ - rarefied Shannon's index of diversity, 1-S - Simpson's unbiased index of diversity, $D W$ - rarity index corresponding to "frequency-downweighted marker values" per population. 

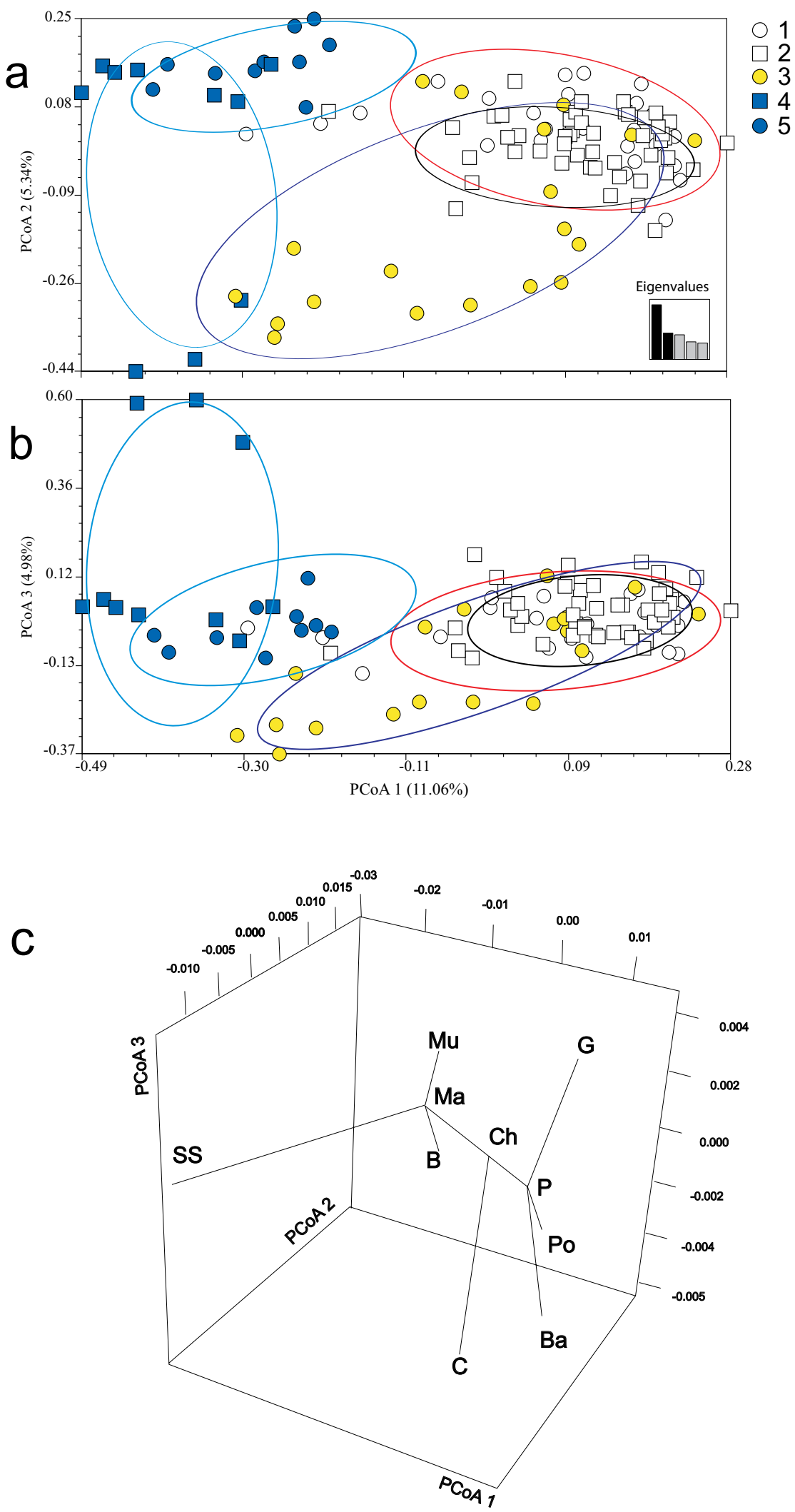

Fig. 3 Principal coordinate analysis (PCoA) of 112 individuals based on Nei-Li distance matrix . a Axes 1 and 2 (inset shows a histogram of the five eigenvalues); b Axes 1 and 3. Elipses denote 95\% confidence intervals of specimens' scores along the axes. A clear distinction between Aconitum firmum and A. plicatum (right) is visible, with intermediate individuals of $A$. $f$. subsp. maninense from Ma population (Slovakia). Axis 3 shows separate position (bottom of the diagram) of eight specimens of $A$. $f$. subsp. maninense from Mu population (the Polish Tatra Mts), and genetic distinctness of three specimens of $A$. p. subsp. sudeticum (top of the diagram). $1-A$. f. subsp. firmum; 2 - A. f. subsp. moravicum; 3 - A. f. subsp. maninense; 4 - A. plicatum subsp. sudeticum; 5 - A. p. subsp. plicatum. c 10 localities of $A$. sect. Aconitum in the Sudetes and W Carpathians, with a minimum spanning tree overlaid (the population SP from the Sudetes was removed as an outlier). Different symbols denote the localities of various taxa with the same abbreviations as those in Tab. 1. Note the nodal position of Pilsko (P) that joins both the Polish (Babia Góra Massif - B, Barania Góra - Ba, Polica - P and Tatra Mts - G), and Czech (Moravskoslezské Beskydy, Mt Chleb - Ch) populations. 
Within A. firmum the most genetically diversified taxon was A. f. subsp. maninense, including genetic richness ( $h$ and $F A r$ indices) and divergence ( $D W$ index, Tab. 1).

In the STRUCTURE analysis the optimal $L(K), \Delta K$ and the highest similarity coefficient among runs $(0.9971, S D=$ 0.0008 ) were given only to those runs in which $K=2$. The geographic distribution of the two genetic groups, Sudetic and Carpathian, is shown in Fig. 1. A part of the sudetic genome (dark) was found in the Carpathian populations. Interestingly, only in those localities where $A$. $f$. subsp. maninense or its hybrids were found in the previous taxonomical study [4].

PCoA (Fig. 3a,b) and NN (Fig. 4) showed a similar pattern of the individuals' grouping to that obtained with the Bayesian assignment analysis (Fig. 1). A plot of the first two PCoA axes showed a separation of A. firmum from A. plicatum and an intermediate position of $A$. $f$. subsp. maninense. The third PCoA axis clearly discriminated eight specimens of A.f. subsp. maninense from the Polish (Mu) population (Fig. 3b). The specimens from the Slovak (Ma) population were mostly introgressed towards $A$. $f$. subsp. firmum and A. f. subsp. moravicum, and one specimen was close to the A. plicatum group. Also, three specimens of $A$. f. subsp. firmum and one specimen of $A$. f. subsp. moravicum (all from the Babia Góra Massif) had genetic links with A. plicatum. Three specimens of $A$. p. subsp. sudeticum were genetically dispatched (Fig. 3a,b).

The PCoA ordination of populations with a minimum spanning tree overlaid showed three nodes (Fig. 3c). The first consisted of Hrubý Jeseník (SS) connected in a node with Manin (Ma), Murzasichle (Mu) and Babia Góra (B). The second was built of Chleb (Ch) and Čeladna (C), and the third included the remaining Carpathian populations $\mathrm{Ba}$, Po and G grouped in a Pilsko node (P).
The most geographically isolated was the Ma population in W Slovakia. NN classification (Fig. 4) showed four main clusters. The first composed of the Sudetic A. plicatum (SP, SS), the second of A.f. subsp. maninense in the Tatra Mts (Mu), together with A.f. subsp. firmum (FB) and A. f. subsp. moravicum (MB) from the Babia Góra Massif, and the third of $A$. $f$. subsp. maninense from the Strážovské vrchy $(\mathrm{Mu}$, Slovakia), joined with A. moravicum from the Moravskoslezské Beskydy (MC, Czech Republic), Beskid Żywiecki (MP and MB) and A. firmum from the Tatra Mts (FG). The fourth group encompassed A. firmum and A. moravicum, mostly introgressed each with other, including the samples from Polish (MBa, MP, MP, MPo MG, FG) and Slovak (MCh) Western Carpathians. This group also encompassed A. maninense: two specimens from Manin (Ma) and two specimens from the Tatra $\mathrm{Mts}(\mathrm{Mu})$.

The AMOVAs showed the differences in the percentage of genetic AFLP variation calculated separately between species and between subspecies within species of Aconitum. The substantial amount of variation was attributed to within-group component in all analyses, amounted to 79-94\%. The highest amount of between-group genetic variance equaled $21 \%$ was found between species, then between the subspecies within A. plicatum (14\%), and the subspecies within A. firmum (6\%). The genetic differences among 11 populations were accounted for by AFLP in 17\%, an intermediate value between the species and subspecies level within A. plicatum (Tab. 2).

Mantel tests of pairwise comparisons between populations based on Nei-Li distances inferred from AFLPs showed significantly positive correlation $r=0.356(P=0.010)$ for a distance class of $21 \mathrm{~km}$.

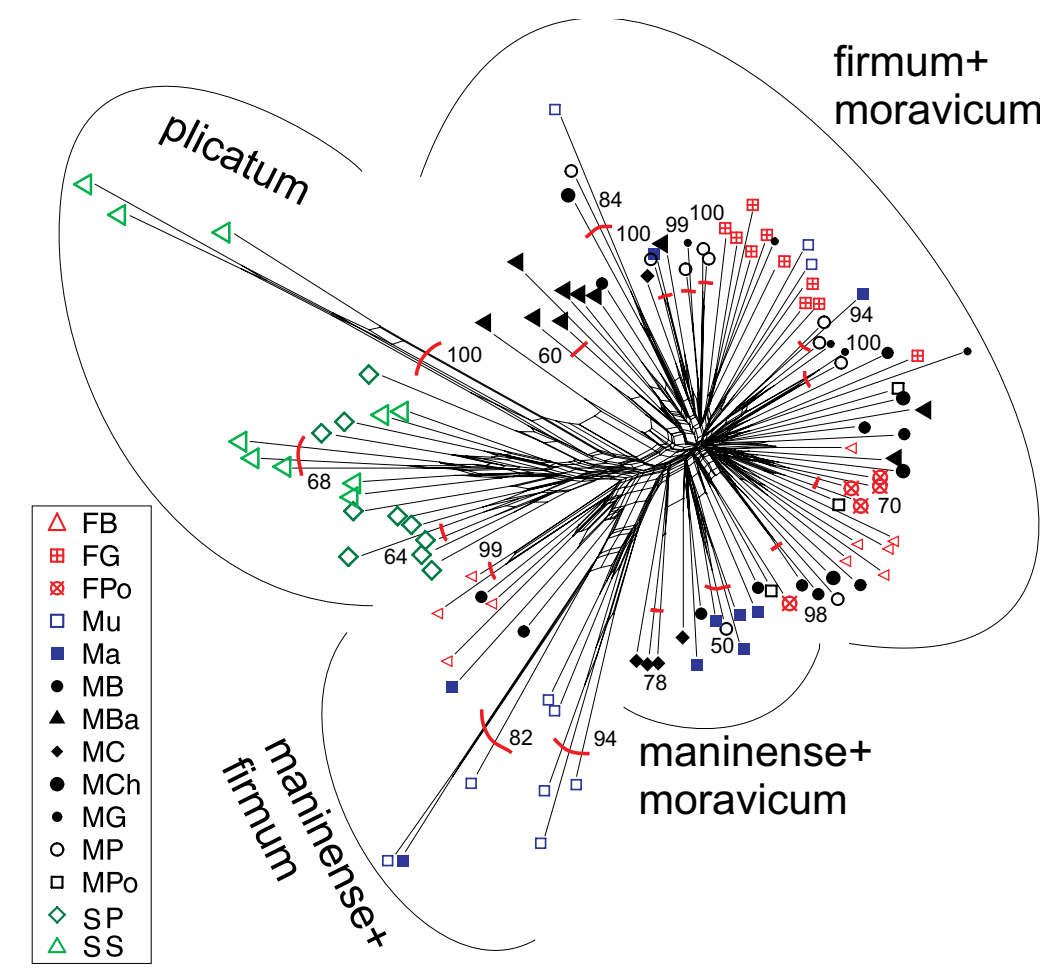

Fig. 4 NeighbourNet classification of 112 individuals of Aconitum in the Sudetes and W Carpathians. Bootstrap values above $50 \%$ (1000 replicates) are presented at each node. For description of localities see Tab. 1. 
Tab. 2 Results of analysis of molecular AMOVA (1000 permutations) for (A) between individuals of subspecies within A. firmum, (B) among individuals of subspecies within A. plicatum, (C) between species A. firmum and A. plicatum, (D) among populations.

\begin{tabular}{|c|c|c|c|c|c|}
\hline Source of variation & d.f. & $\begin{array}{l}\text { Sum of } \\
\text { squares }\end{array}$ & $\begin{array}{c}\text { Variance } \\
\text { components }\end{array}$ & $\begin{array}{l}\% \text { of total } \\
\text { variance }\end{array}$ & $\begin{array}{l}\text { Fixation } \\
\text { index } F_{\mathrm{ST}}\end{array}$ \\
\hline \multicolumn{6}{|c|}{ (A) Among Aconitum firmum subspecies } \\
\hline Among subspecies & 2 & 106.738 & 1.236 & 6 & \multirow[t]{3}{*}{$0.062^{*}$} \\
\hline Within subspecies & 89 & 1657.088 & 18.619 & 94 & \\
\hline Total & 91 & 1763.826 & 19.855 & 100 & \\
\hline \multicolumn{6}{|c|}{ (B) Between Aconitum plicatum subspecies } \\
\hline Between subspecies & 1 & 59.050 & 3.643 & 14 & \multirow[t]{3}{*}{$0.139^{*}$} \\
\hline Within subspecies & 18 & 407.100 & 22.617 & 86 & \\
\hline Total & 19 & 466.150 & 26.260 & 100 & \\
\hline \multicolumn{6}{|c|}{ (C) Between A. firmum and A. plicatum } \\
\hline Between species & 1 & 195.854 & 5.344 & 21 & \multirow[t]{3}{*}{$0.209^{*}$} \\
\hline Within species & 110 & 2229.976 & 20.273 & 79 & \\
\hline Total & 111 & 2425.830 & 25.616 & 100 & \\
\hline \multicolumn{6}{|c|}{ (D) All populations } \\
\hline Among Populations & 10 & 555.364 & 3.694 & 17 & \multirow[t]{3}{*}{$0.166^{*}$} \\
\hline Within Populations & 101 & 1870.467 & 18.519 & 83 & \\
\hline Total & 111 & 2425.830 & 22.213 & 100 & \\
\hline
\end{tabular}

\section{Discussion}

\section{Gene pool of Aconitum plicatum in the Carpathian taxa}

The present results confirm previous findings of genetic links between the Sudetic and Carpathian Aconitum species based on the ISSR + RAPD molecular DNA profiles [3], but indicate a wider geographical context. For example, four individuals of A. firmum from the Babia Góra Massif (three FB A.f. subsp. firmum and one MB A. f. subsp. moravicum) introgressed towards A. plicatum (Fig. 3a). This cryptic introgression, i.e. the genetic change not accompanied by any morphological-taxonomic traits, could be a sign of secondary contact influencing the pattern $[3,12]$. Aconitum plicatum is genetically richer and have the greatest number of unique AFLP bands species. It could be a result of its ancient age linked with genetic isolation. In this line of reasoning the Sudetic genetic stock could have taken a part in the origin of A.f. subsp. maninense. Previous cytogenetic analysis of karyotypes suggests that the genome of the Sudetic autotetraploid (or a close $2 \times$ progenitor of this species) could be ancestral to the Carpathian allotetraploids of the A. firmum group [3]. Among A. firmum, the subsp. maninense is the most genetically divergent ( $D W$ index) and possesses, together with $A$. p. subsp. sudeticum, the same unusual morphological trait - glandular indumentum. All of these point to its relict character.

Generally, the Sudetes, a part of the Hercynian mountain system, were more influenced by the Pleistocene glaciations then the Carpathians, especially by the Mindel glaciation $[39,40]$, and have a closer relationship with other parts of the Hercynian mountain system (Krušne Hory/Erzgebirge, Šumava Mts/Bavarian Forest), and partially with the Eastern Alps, based on the floristic and phylogeographical criteria
$[39,41,42]$. A separate group of the Sudetic high-mountain flora forms the "Carpathian migroelements", which are characterized by species known from one to three mountain ranges in the Sudetes and numerous ranges in the Carpathians. The other group consists of species common in the Carpathians and limited to the Eastern Sudetes, namely to the Hrubý Jeseník Mts. Well defined also is the group of native endemic taxa, including Eastern-Sudetic endemics. This group encompasses - in addition to A. sudeticum Campanula gelida Kovanda, Carlina biebersteinii subsp. sudetica Kovanda, Dianthus carthusianorum subsp. sudeticus Kovanda, Plantago atrata subsp. sudetica (Pilger) Holub, and Poa riphaea (Asch. \& Gr.) Fritsch. Their presence may be a manifestation of long-lasting isolation, the existence of various migration routes from the dispersal centers of the species, but also microevolution processes [42] and secondary contacts [3].

The division into the Sudetic A. plicatum and Carpathian A. firmum was confirmed by the present genetic analysis. Statistically significantly higher genetic diversity indices, and the genetic divergence measure - $D W$ index, were found in A. plicatum, in comparison to A. firmum. This could be the effect of the relictual status of $A$. plicatum. According to the AMOVA results the genetic differentiation within A. plicatum $\left(F_{\mathrm{ST}}=0.139, P<0.001\right)$ was greater than within A. firmum $\left(F_{\mathrm{ST}}=0.062, P<0.001\right)$, linked most probably with its geographical isolation and ancient age.

A similar outcome was found in a subalpine tall-herb Ranunculus platanifolius L. The Sudetic populations were characterized by one of the highest values of the genetic diversity indices of the species in the geographical range $(P P B$ $=36.1 \%, I=0.20, D W=6.93$ ) [41]. In a study on Pulsatilla vernalis (L.) Mill., a high-mountain species descending to 
lowlands, a close genetic relationship between the Tatra (W Carpathians) and Sudetic populations was found based on cpDNA analysis [43]. The examples show that the highmountain flora in the Sudetes and Tatra Mts. has relictual character and could have evolved from the common genetic stock. Nevertheless, the phylogeographic information regarding the Sudetes Mts. is nowadays scarce, and their ancient age and geologically unique position among mountain ranges in Central Europe makes them a very interesting object for evolutionary studies.

\section{Geographic isolation and genetic differentiation in Aconitum}

The basic question is whether the AFLP genetic differentiation reflects the taxonomic pattern. In fact, the taxonomic divisions were corroborated by the genetic fingerprinting only at the specific level. The infraspecific taxonomic distinctions were often blurred by the introgressions. The results of the present study showed that the geographic pattern, exemplified by the isolation-by-distance model, plays significant role in the shaping of the population genetic structure of Aconitum. A Mantel test showed the genetic similarity of the populations autocorrelated in a distance of ca. $20 \mathrm{~km}$. Within these limit the genetic structure of Aconitum could be leveled by the stochastic events. The distance is probably related to average effective seeds dispersal in the mountain conditions, presumably linked with pastoral husbandry. Nevertheless, the infraspecific taxonomic status of some A. firmum populations in the Western Carpathians was still clearly recognized, in spite of their partially homogenized genetic structure. Aconitum species in sympatric areas form hybridogenus taxa. For example, in a study on Aconitum sect. Cammarum in the Western Carpathians among seven individuals genetically classified as later-generation hybrids (introgressants), five of them were taxonomically pure A. variegatum L. (cryptic introgression), and only two of them were identified as a hybridogenous species $A$. $\times p a w$ lowskii Mitka \& Starmühl. [12].

A weaker genetic differentiation was found in the $\mathrm{W}$ Carpathian A. firmum group than in the Sudetic A. plicatum. An exception was $A$. $f$. subsp. maninense, which formed a separate genetic group in the isolated population $\mathrm{Mu}$ in the PCoA analysis. It has narrow geographical range and occurs only in two regions: in the Tatra Mts. and Stražovské vrchy. Its hybrid $A$. ×paxii Starmühl. (A. maninense $\times$ A. moravicum) occurs also in the Babia Góra Massif [4]. Aconitum $f$. subsp. maninense and its hybrids are peculiar in the Carpathians for their glandular hair indumentum. In Aconitum the subspecies are held as the geographic races of the species, with own, partially allopatric geographic ranges, and areas of sympatric occurrence where putative taxonomic hybrids (nothosubspecies) could be formed [4].

Among the Western Carpathian taxa the genetic divergence $D W$ index was the highest in A.f. subsp. maninense that points to its long-term isolation. The population-genetic analysis showed the differentiation of the taxon into two subgroups according to geographical distribution. The first was in the Polish Western Carpathians, and the second in the Stražovské vrchy (Slovakia), where each formed an isolated cluster along the PCoA axis 3 and in NN clustering. The two populations are located within a distance of some
$100 \mathrm{~km}$ on both sides of the main Carpathian ridge. The populations of $A$. maninense had high values of the genetic diversity indices and the highest number of unique alleles $(D W=2.549)$, accompanied by the highest number of bands per individual $(F A r=88.5)$. All these point to the relictual character of the taxon accompanied by the introgression.

Seemingly, a vicariant hypothesis linked with the ancient fragmentation of the initial more or less continuous population sounds reasonable. In the Stražovské vrchy (Ma) A. $f$. subsp. maninense grows between calcareous, steep rocks in the river gorge (Ma, Maninska Tiesňava), of a topographic isolated character. In Murzasichle ( $\mathrm{Mu}$, Tatra Mts) it occurs in a spruce forest in bedrock fissures, also in relict site conditions. Taking into consideration the unusual phenotypic trait (glandular indumentum), narrow geographic distribution, high genetic divergence and some relations to A. plicatum, it seems to have the longest evolutionary history in the A. firmum group.

\section{The introgression within A. firmum complex and species protection}

Aconitum $f$. subsp. firmum and $A$. $f$. subsp. moravicum are distributed in the W Carpathians in the opposite geographical east-west clines [4]. The former has its geographical center in the Tatra Mts, the latter in the Moravskoslezské Beskydy; Mt. Pilsko (Beskid Żywiecki) is a place where the two taxa form a genetic node. The second node seen in the PCoA analysis was formed by the populations, in which A. f. subsp. maninese (or its morphological hybrids) have been found: the Babia Góra Massif - B, Manin - Ma, and the Tatra Mts - Mu.

The genetic analysis revealed that there is no clear genetic line of demarcation between the taxonomically well defined subspecies in the sympatric areas of their distribution in the Western Carpathians. Thus, the phenetic-taxonomic differentiation between the subspecies can be accompanied by a cryptic genetic introgression. It is best seen in the $\mathrm{NN}$ analysis. The specimens of $A$. f. subsp. firmum from the Babia Góra Massif (B), Mt Polica (P), and partially from the Tatra Mts $(\mathrm{Mu})$, were included in one cluster together with $A$. $f$. subsp. moravicum originating from the Babia Góra Massif and Mala Fatra (Ch). Similarly, four specimens of $A$. $f$. subsp. firmum (FB) and two specimens of $A$. moravicum in the Babia Góra Massif (MB) were introgressed towards $A$. $f$. subsp. maninense $(\mathrm{Mu})$.

These findings are an important issue in understanding for the conservation of their genetic pool. Aconitum species are included in the European national red lists and are legally protected in the national parks. Aconitum $f$. subsp. moravicum is included in the IUCN red list and NATURA 2000. The hybridization between Aconitum taxa in sympatry is common $[8,42]$ and hence their taxonomic status could have been theoretically under threat. Any alert seems in this regard premature. This is a natural process and a balance of the various morphotypes enables the optimal ecological status of the population to be reached, irrespective of its infraspecific composition. On the other hand, in species conservancy knowledge of the lower-level taxonomic structure of the populations is a necessary component of any expert threat evaluation and an aide in the studies on dynamic population processes. Nevertheless, one should be cautious 
not to limit interpretation of genetic data to the frames of morphological observations with a strong a priori.

\section{Conclusion}

The Linnaean taxonomical structure of Aconitum sect. Aconitum in the Sudetes and Western Carpathians gave a solid background to the generation of the phylogenetic hypothesis. In fact, without the previous knowledge of the taxonomic infraspecific diversity of A. firmum and A. plicatum the proper interpretation of the results of AFLP analysis could not have been possible. It was showed that AFLPs can be phylogenetically informative at lower taxonomic level.

As expected, the genetic analyses gave deeper insight into the complex evolutionary history of the taxon in Central Europe than the morphological analysis alone. The existence of a part of the genetic stock of A. plicatum in the Western Carpathian A. firmum found in a Bayesian STRUCTURE analysis enables an array of phylogenetic hypotheses to be generated. The first is dealt with probably ancient introgressive hybridization between the two endemic species. To the

\section{Acknowledgments}

The paper was financially supported by a NCN grant No. N N303 814440 . The authors are grateful to Dr. Jacqueline M. Trojan, New Mexico State University, for the English improvement, and three anonymous referees for constructive criticism.

\section{Authors' contributions}

The following declarations about authors' contributions to the research have been made: general conception, acquisition of data, statistical analysis and interpretation of data, editing of the manuscript: JM; laboratory molecular analyses, interpretation of results: PB; laboratory molecular analyses, editing of the manuscript: AW; statistical analysis with R package and interpretation of results: WB.

\section{Competing interests}

No competing interests have been declared.

\section{References}

1. Ilnicki T, Mitka J. Chromosome numbers in Aconitum sect. Aconitum (Ranunculaceae) from the Carpathians. Caryologia. 2009;62:198-203.

2. Ilnicki T, Mitka J. Chromosome numbers in Aconitum sect. Cammarum (Ranunculaceae) from the Carpathians. Caryologia. 2011;64:446-452.

3. Mitka J, Sutkowska A, Ilnicki T, Joachimiak AJ. Reticulate evolution of high-alpine Aconitum (Ranunculaceae) in the Eastern Sudetes and Western Carpathians (Central Europe). Acta Biol Cracov Ser Bot. 2007;49:15-26.

4. Mitka J. The genus Aconitum (Ranunculaceae) in Poland and adjacent countries. A phenetic-geographic study. Cracow: Institute of Botany of Jagiellonian University; 2003.

5. Starmühler W, Mitka J. Systematics and chorology of Aconitum sect. Napellus (Ranunculaceae) and its hybrids in the Northern Carpathians and Forest Carpathians. Thaiszia. 2001;10:115-136.

6. Kadota Y. A revision of Aconitum subgenus Aconitum (Ranunculaceae) of East Asia. Utsunomiya: Sanwa Shoyaku Company, Ltd.; 1987.

7. Kita Y, Ito M. Nuclear ribosomal ITS sequences and phylogeny in East Asian Aconitum subgen. Aconitum (Ranunculaceae), with special reference to extensive polymorphism in individual plants. Plant Syst Evol. 2000;225:1-13. http://dx.doi.org/10.1007/BF00985455

8. Krzakowa M, Szweykowski J. A natural hybrid between two different rather old then relatively recent hybridization pointed the previous cytogenetic investigations [3] and relatively wide distribution of the Sudetic genetic stock in the Western Carpathian Aconitum in Poland and Slovakia. However, the presumed old genetic relations were blurred by a relatively new during secondary contacts in the Quaternary glaciations [3]. The gene-flow was mainly from the Sudetes to the Carpathians, and only negligible in the opposite direction. It could be interpreted in the light of various cytogenetic structure of the Sudetic and Carpathian species. Accordingly, A. plicatum should be considered as the oldest, taking its autoploidy, and A. firmum as an allopolyploid descendant, with some chromosome segments originated from A. plicatum [3]. In the A. firmum group, the A.f. subsp. maninense had the greatest genetic links with A. plicatum. The taxon had also the highest genetic specificity in the Western Carpathians, considering its divergence $D W$ index and indices of genetic diversity, $h$ and FAr. It seems that within $A$. firmum complex A.f. subsp. maninense has the most relict character and the longest evolutionary history. The problem needs further studies.

Aconitum species (Ranunculaceae, Dicotyledones) from the Tatry Mountains. Bull Acad Pol Sci Lett Ser B. 1977;25:223-225.

9. Zieliński R. An electrophoretic and cytological study of hybridization between $A$. napellus ssp. skerisorae $(2 \mathrm{n}=32)$ and $A$. variegatum $(2 \mathrm{n}=16)$. I. Electrophoretic evidence. Acta Soc Bot Pol. 1982;51:453464. http://dx.doi.org/10.5586/asbp.1982.042

10. Zieliński R. An electrophoretic and cytological study of hybridization between $A$. napellus ssp. skerisorae $(2 \mathrm{n}=32)$ and $A$. variegatum $(2 \mathrm{n}=16)$. II. Cytological evidence. Acta Soc Bot Pol. 1982;51:465-471. http://dx.doi.org/10.5586/asbp.1982.043

11. Stebbins GL. Polyploidy, hybrididization and invasion of new habitats. Ann Mo Bot Gard. 1985;72:824-832. http://dx.doi. org/10.2307/2399224

12. Sutkowska A, Boroń P, Mitka J. Natural hybrid zone of Aconitum species in the Western Carpathians: Linnaean taxonomy and ISSR fingerprinting. Acta Biol Crac Ser Bot. 2013;55:114-126. http://dx.doi. org/10.2478/abcsb-2013-00015

13. Aleksandrowski P, Mazur S. Collage tectonics in the northeasternmost part of the Variscan Belt: the Sudetes, Bohemian Massif, In: Winchester JA, Pharaoh TC, Vernirers J, editors. Palaeozoic amalgamation in Central Europe. London: Geological Society; 2002. http://dx.doi. org/10.1144/gsl.sp.2002.201.01.12

14. Kryza R, Mazur S, Oberc-Dziedzic T. The Sudetic geological mosaic: Insights into the root of the Variscan orogen. Przegląd Geologiczny. 2004;52:761-773.

15. Ozenda P. La végétation de la chaîne Alpine dans l'éspace montagnard européen. Paris: Masson; 1985.

16. Rögl von F. Palaeogeographic considerations for Mediterranean and Paratethys Seaways (Oligocene to Miocene). Ann Nat Hist Mus Wien. 1998;99A:279-310.

17. Golonka J, Krobicki M, Oszczypko N, Ślączka A. Palinspastic modelling and Carpathian phanerozoic palaeogeographical maps, In: Oszczypko N, Uchman A, Malata E, editors. Palaeotectonic evolution of the Outer Carpathian and Pieniny Klippen Belt Basins. Kraków: Instytut Nauk Geologicznych Uniwersytetu Jagiellońskiego; 2006.

18. Vos P, Hogers R, Bleeker M, Reijans M, van de Lee T, Hornes M, et al. AFLP: a new technique for DNA fingerprinting. Nucleic Acids Res. 1995;23:4407-4414. http://dx.doi.org/10.1093/nar/23.21.4407

19. Bonin A, Ehrich D, Manel S. Statistical analysis of amplified fragment length polymorphism data: a toolbox for molecular 
ecologist and evolutionist. Mol Ecol. 2007;16:3737-3758. http:// dx.doi.org/10.1111/j.1365-294X.2007.03435.x

20. Nei M. Analysis of gene diversity in subdivided populations. Proc Natl Acad Sci USA. 1973;70:3321-3323. http://dx.doi.org/10.1073/ pnas.70.12.3321

21. Krauss SL. Unbiased gene diversity estimates from amplified fragment length polymorphism (AFLP) markers. Mol Ecol. 2000;9:1241-1245. http://dx.doi.org/10.1046/j.1365-294x.2000.01001.x

22. Vekemans X, Beauwens T, Lemaire M, Roldan-Ruiz I. Data from amplified fragment length polymorphism (AFLP) markers show indication of size homoplasy and of a relationship between degree of homoplasy and fragment size. Mol Ecol. 2002;11:139-151. http:// dx.doi.org/10.1046/j.0962-1083.2001.01415.x

23. R Core Team. R: a language and environment for statistical computing [Internet]. 2011 [cited 2015 May 27]; Available from: http:// cran.r-project.org/

24. Oksanen J, Blanchet FG, Kindt R, Legendre P, O’Hara RB, Simpson GL, et al. Vegan: Community Ecology Package. R package version 1.17-4 [Internet]. 2011 [cited 2015 May 27]; Available from: http:// cran.r-project.org/

25. Schönswetter P, Tribsch A. Vicariance and dispersal in the alpine perennial Bupleurum stellatum L. (Apiaceae). Taxon. 2005;54:725-732. http://dx.doi.org/10.2307/25065429

26. Nei M, Li WH. Mathematical model for studying genetic variation in term of restriction endonucleases. Proc Natl Acad Sci USA. 1979;76:5269-5273. http://dx.doi.org/10.1073/pnas.76.10.5269

27. Nei M. Estimation of average heterozygosity and genetic distance from a small number of individuals. Genetics. 1978;89:583-590.

28. Dray S, Dufour AB. The ade4 package: implementing the duality diagram for ecologists. J Stat Soft. 2007;22:1-20.

29. Huson DH, Bryant D. Application of phylogenetic networks in evolutionary studies. Mol Biol Evol. 2006;23:254-267. http://dx.doi. org/10.1093/molbev/msj030

30. Pritchard JK, Stephens M, Donnelly P. Inference of population structure using multilocus genotype data. Genetics. 2000;155:945-959.

31. Falush D, Stephens M, Pritchard JK. Inference of population structure using multilocus genotype data: linked loci and correlated allele frequencies. Genetics. 2003;164:1567-1587.

32. Falush D, Stephens M, Pritchard JK. Inference of population structure using multilocus genotype data: dominant markers and null alleles. Mol Ecol Notes. 2007;7:574-578. http://dx.doi. org/10.1111/j.1471-8286.2007.01758.x
33. Ehrich D. AFLPDAT: a collection of $\mathrm{R}$ functions for convenient handling of AFLP data. Mol Ecol Notes. 2006;6:603-604. http://dx.doi. org/10.1111/j.1471-8286.2006.01380.x

34. Waples RS, Gaggiotti O. What is a population? An empirical evaluation of some genetic methods for identifying the number of gene pools and their degree of connectivity. Mol Ecol. 2006;15:1419-1439. http:// dx.doi.org/10.1111/j.1365-294X.2006.02890.x

35. Evanno G, Regnaut S, Goudet J. Detecting the number of clusters of individuals using the software Structure: a simulation study. Mol Ecol. 2005;14:2611-2620. http://dx.doi. org/10.1111/j.1365-294X.2005.02553.x

36. Excoffier L, Laval G, Schneider S. Arlequin (version 3.0): an integrated software package for population genetics data analysis. Evol Bioinform Online. 2005;1:47-50.

37. Sokal RR. Spatial data analysis and historical processes. In: Diday E, Escoufier Y, Lebart L, Pages J, Schektman Y, Tomassone R, editors. Data analysis and informatics, IV. Amsterdam: Elsevier Science Publishers BV; 1986.

38. Ogden NL, Sokal RR. Directional autocorrelation: an extension of spatial correlograms to two dimensions. Syst Zool. 1986;35:608-617. http://dx.doi.org/10.2307/2413120

39. Pawłowski B. Die Karpaten und die Sudeten - eine vergleichende pflanzengeographische Studie. Arch Naturschutz Landschaftsforch. 1969;9:251-363.

40. Starkel L. Geografia Polski - środowisko przyrodnicze. Warszawa: PWN; 1991.

41. Stachurska-Swakoń A, Cieślak E, Ronikier M. Phylogeography of a subalpine tall-herb Ranunculus platanifolius (Ranunculaceae) reveals two main genetic lineages in the European mountains. Bot J Linn Soc. 2013;171(2):413-428. http://dx.doi. org/10.1111/j.1095-8339.2012.01323.x

42. Kwiatkowski P, Krahulec F. The distribution of high mountain species of vascular plants within the mountains of the Sudetic system. In: Zemanek B, editor. Geobotanist and taxonomist. A volume dedicated to Professor Adam Zając on the 70th anniversary of his birth. Cracow: Institute of Botany, Jagiellonian University; 2011. p. 69-89.

43. Ronikier R, Costa A, Fuertes Aguilar J, Nieto Feliner G, Küpfer P, Mirek Z. Phylogeography of Pulsatilla vernalis (L.) Mill. (Ranunculaceae): chloroplast DNA reveals two evolutionary lineages across Central Europe and Scandinavia. J Biogeogr. 2011;35:1650-1664. http://dx.doi. org/10.1111/j.1365-2699.2008.01907.x 